\title{
PENGARUH PERHATIAN ORANG TUA TERHADAP PRESTASI BELAJAR SISWA KELAS V SD NEGERI 1 KALIWUNGU KUDUS
}

\author{
Edgar Aufar Zulfahmi ${ }^{1}$, Masturi ${ }^{2}$, Imaniar Purbasari ${ }^{3}$ \\ 123PGSD FKIP Universitas Muria Kudus \\ 1edgaraufarzulfahmi@gmail.com,2masturi@umk.ac.id \\ 3imaniar.purbasari@umk.ac.id
}

\begin{abstract}
The attitudes and attention of parents, both father and mother, towards their children in learning activities will have a positive effect on learning outcomes. Parents' attention can be shown by communication. Communication made by parents to their children in an atmosphere of intimacy by asking about their learning at school or the difficulties they face can help children in learning. People who supervise their children's education will be able to find out student achievement so that parents can take action against their children if the child's learning achievement decreases. The research methodology includes the location of this research is SD Negeri Kaliwungu Kudus. The population as well as the sample of all fifth grade students of SD Negeri 1 Kaliwungu Kudus totaled 25 students. In this study. Data collection techniques using observation, questionnaires, documentation, interviews. The data analysis technique used simple lineier regression analysis. The results of the $F$ test obtained $F$ results of 50.612 with a significance of 0.00 so that it can be concluded that there is a variable influence of people's attention on student achievement variables, with the conclusion that if $F$ count is greater than $F$ table or the level of significance / probability is $0.000<0.05$. then the null hypothesis $(\mathrm{Ho})$ is rejected, the Work Hypothesis ( $\mathrm{Ha}$ ) which says there is a variable influence of parental attention on student learning achievement variables is accepted
\end{abstract}

Keywords: Parents' attention, learning achievement

\section{ABSTRAK}

Sikap dan perhatian orang tua baik ayah maupun ibu terhadap anaknya dalam melakukan aktivitas belajar akan menimbulkan pengaruh positif terhadap hasil belajar. Perhatian orang tua dapat ditunjukkan dengan komunikasi. Komunikasi yang dilakukan orang tua kepada anaknya dalam suasana keakraban dengan menanyakan tentang belajarnya di sekolah ataupun kesulitan-kesulitan yang dihadapinya dapat membantu anak dalam belajarnya. Orang yang melakukan pengawasan terhadap Pendidikan anaknya akan dapat mengetahui prestasi belajar siswa sehingga orang tua dapat melakukan tindakan kepada anaknya apabila prestasi belajar anak menurun. Metodologi Penelitian meliputi lokasi penelitian ini adalah di SD Negeri Kaliwungu Kudus. Populasi sekaligus sampel 
semua siswa kelas V SD Negeri 1 Kaliwungu Kudus berjumlah 25 siswa. Teknik Pengumpulan Data menggunakan Observasi, Angket, dokumentasi, wawancara. Teknik analisis data menggunakan analisis regresi linier sederhana. Hasil penelitian. Hasil dari uji $F$ didapat hasil $F$ sebesar 50,612 dengan signifikansi 0,00 sehingga dapat disimpulkan ada ada pengaruh variabel perhatian orang terhadap variable prestasi belajar siswa, dengan penarikan kesimpulan apabila $F$ hitung lebih besar dari $F$ table atau tingkat signifikansi/probabilitas $0,000<0,05$ maka Hipotesis nol $(\mathrm{Ho})$ ditolak, Hipotesis Kerja $(\mathrm{Ha})$ yang berbunyi ada pengaruh variabel perhatian orang tua terhadap variabel prestasi belajar siswa diterima.

Kata Kunci : Perhatian orang tua, prestasi belajar

\section{A. Pendahuluan}

Pendidikan menjadi tanggung jawab semua kalangan yang memerlukan kerja sama antara individu dan lembaga terkait. Jika semua kalangan melaksanakan kewajibannya, maka terciptanya lahan yang kondusif untuk berlangsungnya pendidikan bagi individu dan program pendidikan akan bergerak maju. Keberhasilan atau prestasi yang dicapai siswa dalam pendidikan sesungguhnya tidak hanya memperhatikan mutu dari institusi pendidikan saja, tetapi juga memperlihatkan keberhasilan keluarga dalam memberikan anak persiapan yang baik untuk pendidikan yang dijalani.

Orang tua tentu saja sangat peduli terhadap pendidikan anakanaknya. Banyak orang tua bercitacita agar anaknya mendapat pendidikan yang setinggi- tingginya.
Tidaklah heran jika para orang tua mencari lembaga pendidikan yang tentunya di anggap baik untuk putraputrinya. Orang tua mungkin lupa bahwa lembaga pendidikan yang menjadikan anaknya menjadi manusia yang manusiawi adalah keluarga.

Lingkungan keluarga merupakan salah satu lembaga yang mengemban mengemban tugas dan tanggung jawab dalam pencapaian tujuan Pendidikan umum. Tujuan essensial adalah mengupayakan subyek didik menjadi pribadi yang utuh dan terintegrasi. Untuk mencapai tujuan ini, tugas dan tanggung jawab keluarga (orang tua) adalah menciptakan situasi dan kondisi yang memuat iklim yang dapat dihayati anak-anak untuk memperdalam dan memperluas makna-makna esensial. Pendidikan dalam keluarga memberikan keyakinan agama, nilai 
budaya yang mencakup nilai moral dan aturan-aturan pergaulan serta pandangan, keterampilan, dan sikap hidup yang mendukung kehidupan bermasyarakat, berbangsa dan bernegara kepada anggota keluarga yang bersangkutan (Nasution, 2010).

Prestasi belajar merupakan bukti keberhasilan proses belajar mengajar yang dicapai oleh peserta didik, dan prestasi belajar sangat ditentukan berbagai faktor yang terjadi selama proses belajar mengajar tersebut. Faktor-faktor yang mempengaruhi hasil belajar pada dasarnya dapat dikategorikan ke dalam dua faktor, yaitu faktor yang berasal dari dalam diri pelajar dan faktor yang datang dari luar diri pelajar atau faktor lingkungan. Faktor yang berasal dari dalam diri (faktor instrinsik) individual antara lain minat, kecerdasan, bakat, motivasi dan kemampuan kognitif. Sedangkan faktor yang datang dari luar diri (faktor eksternal) individu antara lain faktor lingkungan yaitu alam, sosial budaya dan keluarga (Djamarah, 2002).

Sikap dan perhatian orang tua baik ayah maupun ibu terhadap anaknya dalam melakukan aktivitas belajar akan menimbulkan pengaruh positif terhadap hasil belajar. Perhatian orang tua dapat ditunjukkan dengan komunikasi. Komunikasi yang dilakukan orang tua kepada anaknya dalam suasana keakraban dengan menanyakan tentang belajarnya di sekolah ataupun kesulitan-kesulitan yang dihadapinya dapat membantu anak dalam belajarnya. Orang yang melakukan pengawasan terhadap Pendidikan anaknya akan dapat mengetahui prestasi belajar siswa sehingga orang tua dapat melakukan tindakan kepada anaknya apabila prestasi belajar anak menurun.

Berdasarkan hasil observasi di SD Negeri 1 Kaliwungu Kudus, prestasi belajar pada Ulangan Mid Semester 2 banyak siswa yang nilai rata-rata semua bidang studi di bawah Kriteria Ketuntasan Minimal (70). Jumlah siswa kelas $\mathrm{V}$ ada 23 siswa. Siswa yang mendapat nilai rata-rata Tuntas atau $\geq 70$ ada sebanyak 35\% (8 siswa) dan $65 \%$ (15 siswa) mendapat nilai rata-rata di bawah KKM.

\section{Berdasarkan}

wawancara dengan guru dan siswa kelas V di SD Negeri 1 Kaliwungu diketahui bahwa penyebab prestasi belajar siswa menurun adalah kurangnya perhatian 
orang tua siswa dalam mengawasi proses pembelajaran di rumah, anak dibiarkan bermain HP, melihat tayangan televisi, tidak dapat membagi untuk belajar dan bermain, kurang memperhatikan faktor kesehatan anak, kurangnya penciptaan suasana belajar yang tidak nyaman, anak dibiarkan belajar sendiri tampa bimbingan orang tua, Rumusan masalah dalam penelitian ini adalah apakah ada pengaruh perhatian orang tua terhadap prestasi belajar siswa kelas V SD Negeri 1 Kaliwungu Kudus. Tujuan penelitian ini adalah untuk mengetahui pengaruh perhatian orang tua terhadap prestasi belajar siswa kelas V SD Negeri 1 Kaliwungu Kudus.

Menurut (Slameto, 2003) perhatian adalah kegiatan yang dilakukan seseorang dalam hubungannya dengan pemilihan rangsangan dari lingkungannya. Selain itu, menurut (Ahmadi, 2009) perhatian berhubungan erat dengan kesadaran jiwa terhadap suatu objek yang direaksi pada suatu waktu. Kesadaran terhadap suatu objek tertentu tidak tetap, ada kalanya meningkat dan ada kalanya menurun. Tingkat kesadaran akan meningkat apabila jiwa mereaksi sesuatu yang meningkat juga. Hal itu tergantung pada pengerahan aktivitas jiwa objek tersebut. Perhatian timbul dengan adanya pemusatan kesadaran terhadap sesuatu.

Menurut (Ahmadi, 2009), ada beberapa faktor yang dapat mempengaruhi perhatian diantaranya sebagai berikut: Pembawaan, Latihan dan Kebiasaan, Kebutuhan, Kewajiban, Keadaan jasmani, Suasana jiwa, Suasana di sekitar, Kuat tidaknya perangsang dari objek itu sendiri. Sebagaimana tercantum dalam Kamus Besar Bahasa Indonesia, "Prestasi belajar adalah penguasaan pengetahuan atau keterampilan yang dikembangkan melalui mata pelajaran, lazimnya ditunjukan dengan nilai yang diberikan oleh guru" Sedangkan (Winkel, 2004) mengungkapkan bahwa proses belajar yang dialami oleh siswa menghasilkan perubahanperubahan dalam bidang pengetahuan dan pemahaman, dalam bidang nilai, sikap dan keterampilan. Adanya perubahan tersebut tampak dalam prestasi belajar yang dihasilkan oleh siswa terhadap pertanyaan, persoalan 
atau tugas yang diberikan oleh guru. Melalui prestasi belajar siswa dapat mengetahui kemajuankemajuan yang telah dicapainya dalam belajar.

Prestasi yang dicapai seorang individu merupakan hasil interaksi antara berbagai faktor yang mempengaruhi, baik dalam diri siswa maupun luar diri siswa. Adapun faktor-faktor yang mempengaruhi prestasi belajar menurut (Syah, 2009), yaitu: Faktor internal (faktor dari dalam diri individu), meliputi keadaan atau kondisi jasmani dan rohani siswa. Faktor eksternal (faktor dari luar diri individu), meliputi kondisi lingkungan sekitar siswa. Faktor pendekatan belajar yaitu jenis upaya belajar siswa (kebiasaan) yang meliputi strategi dan metode yang digunakan siswa untuk melakukan kegiatan pembelajaran materi pelajaran. Faktor-faktor diatas saling berinterkasi secara langsung dalam mempengaruhi prestasi belajar siswa. Oleh karena itu sangat diperlukan lingkungan yang baik dan kesiapan dalam diri siswa yang meliputi strategi, metode serta gaya belajar, agar dapat memberi pengaruh terhadap prestasi belajar yang akan dihasilkan.

Kerangka berpikir :Prestasi merupakan proses perubahan yang dialami siswa dalam bidang pengetahuan dan pemahaman, nilai, sikap dan keterampilan. Perubahan tersebut dihasilkan oleh siswa terhadap pertanyaan, persoalan atau tugas yang diberikan oleh guru. Melalui prestasi belajar siswa dapat mengetahui kemajuan-kemajuan yang telah dicapainya dalam belajar. Prestasi yang dicapai seorang individu merupakan hasil interaksi antara berbagai faktor yang mempengaruhi, baik dalam diri siswa maupun luar diri siswa melalui lingkungan sekolah, lingkungan sekitar dan lingkungan keluarga.

Orang tua berperan sebagai penanggung jawab yang berkewajiban untuk memberi kasih sayang dan cinta yang tulus kepada anak-anaknya. Bentuk kasih sayang yang muncul dalam keluarga biasanya sangat bervariasi, baik secara verbal melalui ucapan/perkataan maupun nonverbal melalui sikap/perbuatan salah satunya berupa perhatian yang diberikan orang tua terhadap anak. 
Dengan demikian untuk membantu agar dapat berprestasi, keterlibatan orang tua dalam keluarga sangatlah penting terutama dalam memberi kasih sayang dan cinta yang tulus kepada anakanaknya. Selain itu, orang tua juga dapat membantu anak dalam pendidikannya dengan cara memperhatikan kesehatan anak, melakukan pengawasan terhadap kegiatan belajar anak, menciptakan suasana belajar yang nyaman untuk kegiatan belajar anak, memenuhi kebutuhan belajar anak, memberikan bimbingan belajar, dan memberi penghargaan dan hukuman terhadap proses belajar yang telah dicapai anak. Hipotesis penelitiannya ada pengaruh perhatian orang tua terhadap prestasi belajar siswa kelas $V \mathrm{SD}$ Negeri 1 Kaliwungu Kudus.

\section{B. Metode Penelitian}

Lokasi penelitian ini adalah di SD Negeri Kaliwungu Kudus. Penelitian ini dilaksanakan pada bulan Juni sampai dengan bulan Agustus 2020. Penelitian ini merupakan penelitian korelasional dengan pendekatan kuantitatif. Proses penelitian kuantitatif bersifat linier, dimana langkah-langkahnya jelas dan dilakukan secara beratur mulai dari rumusan masalah, teori, hipotesis, pengumpulan data, analisis data hingga membuat kesimpulan dan saran. Penelitian dengan pendekatan korelasional dimaksudkan untuk mengetahui ada tidaknya hubungan antara dua variabel. Besar atau tingginya hubungan tersebut kemudian dinyatakan dalam bentuk koefisien korelasi Populasi penelitian ini adalah semua siswa kelas $V$ SD Negeri 1 Kaliwungu Kudus, populasi penelitian berjumlah 25 siswa. Populasi Variabel menurut (Arikunto, 2016) adalah obyek penelitian atau lebih detailnya yaitu suatu konsep yang mempunyai variabel atau keragaman.

Teknik Pengumpulan Data meliputi Observasi pada penelitian ini yaitu menggunaan observasi non partisipasi yang artinya yaitu dalam pelaksanaan observasi, peneliti tidak terlibat sebagai partisipasi atau kelompok yang diteliti. Observasi yang dilakukan peneliti dipergunakan untuk melihat aktivitas siswa dalam proses pembelajaran. Angket Angket dipergunakan untuk mengungkap data variabel perhatian orang tua $(X)$. 
Dokumentasi. Teknik ini digunakan untuk mengungkap variabel prestasi belajar $(\mathrm{Y})$, yang diperoleh dari nilai ulangan tema 1 (satu) tahun pelajaran 2020/2021 Wawancara. Sugiyono (2016:194) wawancara digunakan sebagai Teknik pengumpulan data apabila peneliti ingin melakukan studi pendahuluan untuk menemukan permasalahan yang harus diteliti dan juga apabila peneliti ingin mengetahui hal-hal dari responden yang lebih mendalam dan jumlahnya respondennya sedikit atau kecil. Wawancara dilakukan dengan menyiapkan instrument berupa pertanyaan - pertanyaan tertulis yang dipergunakan untuk mengetahui kondisi awal sebelum melaksanakan penelitian. Instrumen pengumpulan data dalam penelitian ini berupa observasi digunakan untuk melihat aktivitas siswa dalam proses pembelajaran.Indikator dari observasi adalah keaktifan dalam proses pembelajaran. Instrumen pengumpulan berupa angket tentang perhatian orang tua sebanyak 20 butir. Jawaban setiap item instrumen menggunakan skala Likert. Pada penelitian ini menggunakan alternatif jawaban selalu, sering, kadangkadang, dan tidak pernah. Siswa dapat memilih pernyataan yang sesuai dengan keadaan yang sebenarnya dalam bentuk checklist pada alternatif jawaban yang ada. Instrumen dokumentasi mengungkap variabel prestasi belajar (Y). Indikator dari instrumen dokumentasi ini adalah nilai ulangan tema 1 . Wawancara dilakukan dengan menyiapkan instrument berupa pertanyaan-pertanyaan tertulis yang digunakan untuk mengetahui kondisi awal sebelum melaksanakan penelitian.

Uji Validitas (Arikunto, 2016) mengemukan bahwa sebuah butir angket dikatakan valid apabila angket tersebut dapat mengukur apa yang hendak diukur atau sahih atau kuat. Validitas dalam penelitian ini menggunakan analisis butir dengan menggunakan rumus korelasi product moment. Untuk menentukan valid tidaknya item angket hasil rxy ikonsultasikan ke tabel harga kritik $r$ product moment. Jika harga $r$ lebih besar dari harga kritik dalam tabel, maka korelasi tersebut valid, begitu juga arti sebaliknya. Uji Reliabilitas Reliabilitas menunjuk pada satu pengertian bahwa sesuatu instrument cukup dapat dipercaya untuk digunakan sebagai alat pengumpul 
data karena instrument tersebut sudah baik (Arikunto, 2016). Dalam penelitian ini penulis menggunakan rumus Alpha untuk mencari reliabilitas angket. Jika $r_{11}$ telah ditemukan maka langkah selanjutnya mengkonsultasikan harga tersebut dengan tabel $r$ product moment. Jika angka perolehan $r$ hitung $\left(r_{11}\right)$ lebih besar daripada $r$ tabel maka angket dinyatakan reliabel dan berlaku sebaliknya jika $r$ hitung $\left(r_{11}\right)$ lebih kecil daripada $r$ tabel maka angket tersebut dinyatakan tidak reliabel.

Teknik Analisis Data 1. Analisis Tahap Awal. Analisis tahap awal meliputi Uji normalitas adalah bentuk pengujian tentang kenormalan distribusi data. Tujuan dari uji normalitas adalah untuk mengetahui apakah data yang diambil merupakan data distribusi normal atau bukan (Kariadinata, Rahayu, Abdurrahman, 2012). Angket yang disebarkan kepada siswa diuji normalitas menggunakan uji Kolmogorov Smirnov. Untuk menentukan normalitas dari data tersebut cukup membaca nilai signifikansi (Asymp Sig 2 - tailet). Jika signifikan kurang dari 0,05 , maka kesimpulannya data tidak berdistribusi normal. Tetapi jika nilai signifikansi lebih dari 0.05 maka data tersebut berdistribusi normal (Priyono, 2012) Analisis Tahap Akhir Langkah analisis tahap akhir adalah Uji Hipotesis Uji Hipotesis Pengujian hipotesis pada penelitian ini menggunakan regresi linier sederhana yang diuji dengan bantuan program SPSS versi 25.0 Mencari persamaan regresi dapat menggunakan rumus sebagai berikut.

$$
Y^{\prime}=a+b X
$$

Keterangan:

$Y^{\prime}=$ nilai yang diprediksikan

$a=$ konstanta atau bilangan harga $X=0$

$b=$ koefisien regresi

$X=$ nilai variabel independent

Hasil dari uji F dapat menjelaskan apakah ada pengaruh variable $X$ terhadap variable $Y$, dengan penarikan kesimpulan apabila $\mathrm{F}$ hitung lebih besar dari $\mathrm{F}$ table atau tingkat signifikansi/ probabilitas $0,000<0,05$ maka Hipotesis nol (Ho) ditolak, Hipotesis Kerja ( $\mathrm{Ha}$ ) yang berbunyi ada pengaruh variabel perhatian orang tua terhadap variabel prestasi belajar siswa.

\section{Hasil Penelitian dan \\ Pembahasan}

Uji Validitas untuk menemukan bahwa sebuah butir angket dikatakan valid apabila angket tersebut dapat 
mengukur apa yang hendak diukur atau sahih atau kuat. Validitas dalam penelitian ini menggunakan analisis butir dengan menggunakan rumus korelasi product moment Untuk menentukan valid tidaknya item angket hasil rxy ikonsultasikan ke tabel harga kritik $r$ product moment. Jika harga $r$ lebih besar dari harga kritik dalam tabel, maka korelasi tersebut valid, begitu juga arti sebaliknya. Dari perhitungan validitas di atas dari nomor item 1 sampai dengan 20 didapat hasil $r$ hitung dari ke 20 item lebih besar dari $r$ product moment dengan $\mathrm{N}=20$ dengan taraf signifikansi $5 \%$ sebesar 0,444, sehingga dapat disimpulkan semua item angket valid untuk digunakan mengambil data penelitian.

Reliabilitas menunjuk pada satu pengertian bahwa sesuatu instrument cukup dapat dipercaya untuk digunakan sebagai alat pengumpul data karena instrument tersebut sudah baik. Dalam penelitian ini penulis menggunakan rumus Alpha untuk mencari reliabilitas angket. Berdasarkan hasil perhitungan relibilitas didapat hasil 0,989 lebih besar dari $r$ Tabel 0,444 sehingga dapat disimpulkan angket penelitian perhatian orang tua reliabel untuk mengambil data penelitian.

Uji normalitas merupakan salah satu bagian dari uji persyaratan analisi data sebelum melakukan analisis statistic untuk uji hipotesis dalam hal ini adalah analisis regresi, maka data penelitian tersebut harus diuji kenormalan distribusinya. Data yang baik apabila data tersebut berdistribusi normal. Uji normalitas dilakukan dengan tujuan untuk mengetahui apakah dalam model regresi, variabel residu memiliki distribusi normal atau tidak. Untukmenentukan normal atau tidaknya distribusi data dilakukan dengan uji Kolmogorov Smirnov. Uji normalitas menggunakan program SPSS versi 16 dengan hasil Untuk menentukan normalitas dari data tersebut cukup membaca nilai signifikansi (Asymp Sig 2 - tailet). Jika signifikan kurang dari 0,05, maka kesimpulannya data tidak berdistribusi normal. Tetapi jika nilai signifikansi lebih dari 0.05 maka data tersebut berdistribusi normal. Berdasarkan tabel out SPSS tersebut diketahui nilai asyimp.sig sebesar 0, 200 lebih besar dari 0,05 maka sesuai dengan dasar pengambilan keputusan dalam uji normalitas Kolmogorov smirnov 
diatas maka dapat disimpulkan data berdistribusi normal.

Analisis regresi sederhana digunakan untuk mengukur pengaruh variabel perhatian orang tua terhadap prestasi belajar siswa Uji Hipotesis Pengujian hipotesis pada penelitian ini menggunakan regresi linier sederhana yang diuji dengan bantuan program SPSS versi 25.0 . persamaan regresi dapat menggunakan rumus sebagai berikut. $Y^{\prime}=48,388+0,378 \times$ Keterangan: $Y^{\prime}=$ prestasi belajar, $a=48,388$. Angka ini merupakan angka konstan yang mempunyai arti jika tidak ada perhatian orang tua maka nilai konsistensi prestasi belajar siswa adalah 48,388, $b=$ Angkat koefisien regresi sebesar 0,378.

Angka ini mengandung arti setiap penambahan $1 \%$ tingkat perhatian orang tua maka prestasi belajar siswa akan meningkat 0,378. Karena nilai koefisien regresi bernilai positif maka dapat dikatakan bahwa perhatian orang tua berpengaruh positif terhadap prestasi belajar siswa . Untuk memastikan apakah koefisien regresi itu signifikan atau dalam arti variabel perhatian orang tua berpengaruh terhadap prestasi belajar siswa dapat dilakukan uji hipotesis dengan cara membandingkan nilai signifikansi (sig) dengan probabalitas 0,05. Jika nilai signifikansi (sig) lebih kecil dari probabilitas 0,05 mengandung arti bahwa ada pengaruh perhatian orang tua terhadap prestasi belajar siswa, sebaliknya kalo lebih probabilitasnya lebih besar dari 0,05 maka tidak ada pengaruh.

Hasil dari uji $F$ didapat hasil $F$ sebesar 50,612 dengan signifikansi 0,00 sehingga dapat disimpulkan ada ada pengaruh variable perhatian orang terhadap variable prestasi belajar siswa, dengan penarikan kesimpulan apabila $\mathrm{F}$ hitung lebih besar dari $F$ table atau tingkat signifikansi/probabilitas $\quad 0,000<0,05$ maka Hipotesis nol (Ho) ditolak, Hipotesis Kerja (Ha) yang berbunyi ada pengaruh variabel perhatian orang tua terhadap variabel prestasi belajar siswa.

\section{Kesimpulan}

Simpulan dalam penelitian ini yaitu: 1) Prestasi belajar siswa kelas $V$ pada ulangan tema 1 secara daring mencapai 71,36 sudah melalui Kriteria Ketuntasan Minimal yang ditetapkan oleh sekolah sebesar 70. 2) Hasil dari uji F didapat hasil F sebesar 50,612 
dengan signifikansi 0,00 sehingga dapat disimpulkan ada ada pengaruh variable perhatian orang terhadap variable prestasi belajar siswa, dengan penarikan kesimpulan apabila $\mathrm{F}$ hitung lebih besar dari $\mathrm{F}$ table atau tingkat signifikansi/probabilitas $0,000<0,05$ maka Hipotesis nol $(\mathrm{Ho})$ ditolak, Hipotesis Kerja (Ha) yang berbunyi ada pengaruh variabel perhatian orang tua terhadap variabel prestasi belajar siswa

Berdasarkan hasil penelitian dan pembahasan yang telah dipaparkan, maka saran yang dapat diberikan adalah sebagai berikut: 1) Hendaknya lebih memperhatikan kebutuhankebutuhan yang dapat menunjang prestasi belajar. Tidak hanya memperhatikan kesehatan anak saja namun juga dalam hal pemenuhan kebutuhan belajar, penciptaan suasana belajar yang nyaman, pengawasan kegiatan belajar, memberikan bimbingan belajar, dan pemberian penghargaan dan hukuman.

\section{DAFTAR PUSTAKA}

Ahmadi, A. (2009). Psikologi Umum. Jakarta: Rineka Cipta.

Arikunto, S. (2016). Metode Penelitian. Jakarta: Rineka Cipta.
Djamarah, S. B. (2002). Psikologi Belajar. Jakarta: PT Rineka Cipta.

Kariadinata, Rahayu, Abdurrahman, M. (2012). Dasar-dasar Statistik Pendidikan. Bandung: CV Pustaka Setia.

Nasution. (2010). Berbagai Pendekatan dalam Proses Belajar dan Mengajar. Jakarta: Bumi Aksara.

Priyono. (2012). SPPS Versi 23. Jakarta: Rineka Cipta.

Slameto. (2003). Belajar dan Faktorfaktor yang Mempengaruhinya. Jakarta: Rineka Cipta.

Syah, M. (2009). Psikologi Pendidikan dengan Pendekatan Baru. Bandung: Remaja Rosdakarya.

Winkel. (2004). Psikologi Pengajaran. Yogyakarta: Media Abadi. 